\title{
ARTÍCULOS
}

\section{TRANSPARENCY IN CITIZEN PARTICIPATION TOOLS AND PUBLIC INFORMATION: A COMPARATIVE STUDY OF THE SPANISH GITY COUNCILS' WEBSITES}

Transparencia en las herramientas de participación ciudadana e información pública: Comparación de las webs de los municipios españoles

\section{Marta Rebolledo, Rocío Zamora-Medina and Jordi Rodríguez-Virgili}

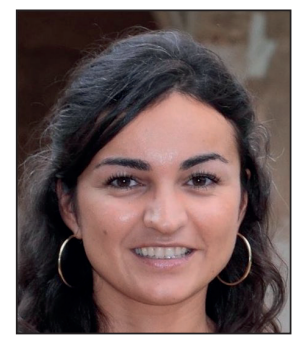

Marta Rebolledo is professor of Political Communication and Global Communication at the University of Navarra and holds an international double doctoral degree from the same institution and I'Université Paris-Est (France). Her research mainly focuses on political marketing, election campaigns, and transparency and public communication from institutions. She has been a visiting scholar at The George Washington University (USA) and Loughborough University (UK). http://orcid.org/0000-0003-0986-7332

Department of Public Communication, School of Communication, University of Navarra 31080 Pamplona, Spain mrebolledo@unav.es

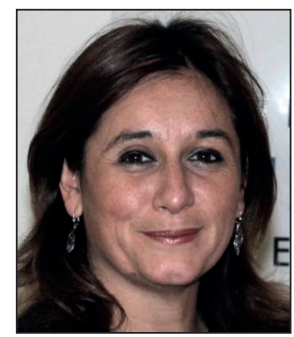

Rocío Zamora-Medina is professor of Communication Theories at University of Murcia. She has a wide international teaching and research experience. She belongs to the Research Group in Ciberdemocracy at Universidad Complutense de Madrid (UCM) and the Research Group in Communication, Culture, and Technology at University of Murcia. She launched Asociación de Comunicación Política (ACOP), the largest (scholars and practitioners) political communication association, being coordinator for national research on Political Communication. https://orcid.org/0000-0002-0541-2456

University of Murcia, Faculty of Communication and Information Sciences Campus de Espinardo, s/n. 30100 Espinardo (Murcia), Spain rzamoramedina@um.es

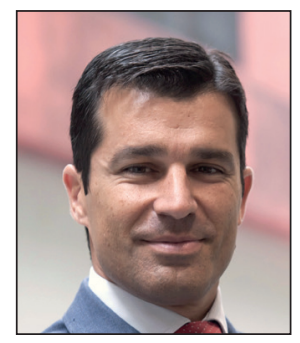

Jordi Rodríguez-Virgili is professor of Political Communication at the University of Navarra (UNAV) and Vice dean of Teaching Staff and Academic Organization of its Faculty of Communication. He is a researcher at the Centre for Internet Studies and Digital Life at the UNAV. In 2016 he was awarded the Victory Award for Merit for Excellence in Teaching in Political Communication. He has been director of the Master's degree program in Political and Corporate Communication (MCPC) at UNAV. http://orcid.org/0000-0002-7952-5664

Department of Public Communication, School of Communication, University of Navarra 31080 Pamplona, Spain jrvirgili@unav.es

\begin{abstract}
Communication is indispensable for institutions in regaining trust and credibility among citizens. In this context, transparency management and the promotion of citizen participation online are essential. After December 2015, when the Spanish transparency law 19/2013 was fully in force at the local level, all local municipalities were required to show all the public information on their websites published in a clear and understandable way. This requirement turns the Spanish local administrations into an interesting case study to assess efforts to improve their relationships with their citizens; hence this research aims to measure the Spanish transparency level on public information and participation. For that purpose, a set
\end{abstract}


of indicators were used to analyze the content of those websites that corresponded to a representative sample of municipalities with 10,000 or more inhabitants $(\mathrm{N}=394)$. Findings pointed to a very low transparency level and major deficiencies related to online engagement with resources that are required by law.

\section{Keywords}

Public information; Transparency; Participation; Accountability; Local government.

\section{Resumen}

La comunicación es clave para que las instituciones recuperen la confianza y credibilidad de los ciudadanos. En este sentido, la gestión de la transparencia y la promoción de la participación ciudadana online son dos aspectos esenciales. Tras la entrada en vigor a nivel local en diciembre de 2015 de la Ley 19/2013 de transparencia, acceso a la información pública y buen gobierno, los ayuntamientos de España están obligados a publicar de forma clara y comprensible toda la información pública en sus sitios web. Este requisito convierte a las administraciones locales españolas en un interesante caso de estudio para evaluar los esfuerzos de mejora en la relación con sus ciudadanos. De ahí que el objetivo de este estudio sea medir el nivel de transparencia en las herramientas de información pública y participación. Para ello se compara una muestra representativa de los sitios web de ayuntamientos con más de 10.000 habitantes $(\mathrm{N}=394)$ utilizando un conjunto de indicadores específicos para el análisis de contenido. Los resultados indican un nivel de transparencia muy bajo así como importantes carencias y deficiencias relacionadas con los recursos de participación online.

\section{Palabras clave}

Información pública; Transparencia; Participación; Rendición de cuentas; Ayuntamientos.

Rebolledo, Marta; Zamora-Medina, Rocío; Rodríguez-Virgili, Jordi (2017). "Transparency in citizen participation tools and public information: A comparative study of the Spanish city councils' websites". El profesional de la información, v. 26, n. 3, pp. 361-369.

https://doi.org/10.3145/epi.2017.may.02

\section{Introduction}

Institutions, as social entities that manage the assets and rights of citizens, are facing an uncertain context marked, on one hand, by a loss of credibility from citizens and, on the other hand, by a participation request that is more and more intense. Initiatives are developed by civil society to convey their message of protest and express their desire to participate in political decision-making. Under these circumstances, communication is more essential than ever in order for institutions to regain the trust and credibility of citizens (Norris, 2000) and the management of transparency that fosters informed participation by citizens is an indispensable requirement to do so (Bauhr; Grimes, 2014).

With the approval of the Law for transparency, access to public information and good governance on the ninth of December, 2013, Spain delivered an interesting case study that allows us to assess the efforts of local governments in improving their relationships with citizens (España, 2013). This law compels public administrations to actively publicize relevant institutional information on their websites and to respond to citizen requests for public information (BeltránOrenes; Martínez-Pastor, 2016). In this way, the act obliges Spanish municipalities to make available, within in two years, pertinent data for public knowledge and obey to all the requirements contained on it (España, 2013). Moreover, another aspect that makes Spain a particularly salient case study regarding transparency is the level of political corruption, which is a major problem (CIS, 2016). In this context, the increased availability of public information provided by new communication technologies can be used as an instrument to restore the credibility of institutions from the citizens' points of view.
At the local level of government it is evident there is a need for transparency, accountability, and participation. This local context is precisely the setting of choice for this research. The main objective of this study is to analyze how digital technology is used to communicate on the websites of municipalities: resources, features, and practices. The management of local communication represents a convenient starting point, since this close environment deals with and solves matters of everyday life, in contrast with national and global issues (Zamora-Medina, 2011). Local governments also enjoy a greater level of trust from citizens, compared to national institutions (Kim; Lee, 2012).

In this particular case, the content of websites of a representative sample of Spanish municipalities with 10,000 or more inhabitants were analyzed, for a total of 394 websites. Regarding the analysis, the transparency indicators used in this research focused on two dimensions: first, indicators related to the public information shared by local municipalities, such as news about government management and the municipal agenda; second, indicators linked to participation tools provided for citizens' use, such as mechanisms for taking part in the debate of current topics of local interest.

This study is the result of a research \& development project Public communication, transparency, accountability, and participation in local government (reference CSO 201346997-R), a collaboration of several Spanish universities funded by the Spanish Ministry of Economy and Competitiveness. This project seeks to analyze communication in all local governments in Spain and it is in turn inspired by an earlier study entitled Communication and journalism for citizen participation in monitoring and evaluating the management of local governments (CSO 2012-34687). For that, a 
relevant tool has been used: the Mapa Infoparticip@ platform, which shows how local public administrations make use of the Internet and new media to promote accountability and transparency.

http://www.mapainfoparticipa.com

The main goal of this new project is to complete the work previously done and continue the coverage of the Mapa Infoparticip@ platform in 10 other autonomous communities, in order to obtain a complete picture of the Spanish national territory. The research presented here aims to offer an overview of the level of transparency in Spanish local governments focusing specifically on the public information provided to citizens and participation tools as well, in the range of municipalities with 10,000 or more inhabitants.

\section{Analytical framework}

Transparency has become a recurring theme in research in areas such as Communication and Political Science. In the frame of the so-called 'electronic democracy' or 'cyberdemocracy' and a new digital environment, transparency stands as an essential condition to respond to the increasing demand for a more open way of government. According to the organization Transparency International, the term transparency refers to "the quality of a government, company, organization or person to be open in disclosing information, policies, plans, processes and actions. As a general rule, civil servants, public employees, managers and directors of companies and organizations, and boards have an obligation to act visibly, predictably and understandably to promote participation and accountability" (quoted in Lizcano, 2012, p. 161). Specifically, in the political arena, this term is directly related to political control and accountability, and citizen participation as well.

The aspect of accountability deals, in a general sense, with the knowledge by the public of what happens within public institutions, an essential element for democratically functioning politics. Transparency has become a fundamental value of democracy; it facilitates monitoring the activity of charges and hinders abuses of power and corruption that proliferate in contexts of opacity. In this sense, the more information citizens have at their disposal to exercise effective control of the management of public affairs the more the gap between rulers and ruled will decrease.

A number of studies have previously been conducted about the transparency and accountability of governments (Villoria, 2011; Alguacil-Gómez, 2006; Guerrero, 2006; LabioBernal, 2006; Molina-Rodríguez-Navas, 2008; Reig, 2009; Gértrudix et al., 2016 among others). In addition, under the umbrella of the project entitled Communication and journalism for citizen participation in monitoring and evaluating the management of local government (CSO 2012-34687) mentioned above, findings and conclusions have been published on the topic (Moreno-Sardà; Molina-RodríguezNavas; Corcoy-Rius, 2013a; Moreno-Sardà et al., 2013b; Rebolledo; Zamora-Medina; Rodríguez-Virgili, 2016).

Transparency of public activities is in turn a means of encouraging citizen participation in decision-making and in the management of relevant affairs, as well as reducing injustice and, ideally, corruption (Stasavage, 2003). In this way, the demand for transparency is a basic claim in order to advance towards more participatory forms of democracy and to substantiate the act of participation itself.

Nowadays, public representatives and political parties are both dealing with a complicated scenario with different challenges to be faced regarding citizen participation, an aspect increasingly in demand from civil society. Elections no longer represent the most general way for citizens to participate in democracy, but other actions are now emerging, favored by new technologies and related to democratic regeneration (Verge, 2007).

Apart from accountability and political control, the aspect of responsiveness from institutions also seems essential. Due to the distrust towards political agents, it is necessary that institutions arbitrate, in some way, procedures that collect the demands of the citizens between elections, while also serving to empower the citizenship in the control to politicians. In this sense, in Europe in recent years, different instruments enabling active citizen participation have been implemented at the local level (Tornos-Mas et al., 2012). An example of this is the so-called 'participatory budgeting', conceived of as a way for citizens to participate in public management through the inclusion of new citizen demands in the preparation of budgets.

The increased availability of public information provided by new communication technologies can be used as an instrument to restore the credibility of institutions from the citizens' points of view

The culture of transparency and participation requires a change of mentality when using public information, with greater equanimity and plurality. It makes no sense to have an enormous amount of stored documents if there is no policy to make it accessible, encourage use, or promote interaction with citizens, and politicians assume the duty to account for their responsibilities as well (Bauhr; Grimes, 2014; Lindstedt; Naurin, 2010). At a time marked by the loss of credibility in politics, communication based on transparency is an essential aspect in regaining the confidence of citizens in their political representatives.

\section{Objectives and hypothesis}

As noted above, the websites of local councils of Spanish autonomous communities have been analyzed as the object of this case study. The main objective is to analyze and assess how the city councils use digital technologies in their relationship with citizens. For that purpose, this study focuses on the transparency level of public information and participation tools.

Previous studies have identified an unsatisfactory level of transparency on city council websites, revealing accountability deficiencies by governments (Cabezuelo-Lorenzo; ReyGarcía; Tapia-Frade, 2016; Manfredi-Sánchez et al., 2016; Rebolledo; Zamora-Medina; Rodríguez-Virgili, 2016; Moreno-Sardà et al., 2015) ${ }^{1}$. Not only was the amount of public 
information available on the platforms deficient, but also the way it was provided for citizens: there was a lack of relevant information (legislative projects, agreements and contracts signed, action plans); the data on the websites was not wellexplained nor conveyed to the citizens; the information presented was not neutral, accessible or reliable; there were not tools devoted to interact with citizens, among other aspects.

For our study we also identify secondary objectives to better explore the differences in transparency level among municipalities. First, our aim is to analyze how the transparency level differences correlate to the size of municipalities, in order to empirically assess the impact of this variable on transparency scores. Second, we will test the relationship between transparency level and citizen participation level.

Based on these objectives, this research is based on two hypothesis:

(H1) The first underlines that there are differences in transparency and participation level depending on the size of the municipality -the larger the size is, the better results in participation and transparency are-. The larger municipalities will have a greater degree of transparency and encourage a more fluid relationship, thanks to the technologies used, than those with a smaller population, mainly due to the greater availability of resources. This difference is statistically significant.

(H2) The second hypothesis is that there are differences in the level of participation depending on the score obtained in the other two blocks of indicators, that is, transparency related to information on the local representatives and government on the one hand; and transparency linked to management of economic resources on the other hand. In that sense, the higher score in transparency, the higher score in citizen participation.

The culture of transparency and participation requires a change of mentality when using public information, with greater equanimity and plurality

\section{Methodology}

To test both hypotheses, a quantitative analysis of the presence/absence of a set of indicators that measure the level of transparency and citizen participation offered by the local councils websites included in the sample will be conducted.

To evaluate the information provided, a set of indicators have been designed, not so much to assess the transparency of management, but more to evaluate the provision of basic information, so that anyone can identify how the political leaders of local governments are managing public resources. In a first wave of analysis, 41 indicators based on the Decalogue of good practices of local public communication that were initially used by some scholars to test the catalonian municipalites websites (Moreno-Sardà et al., 2013a) will be used.

http://labcompublica.info/es/innovacion/decalogo-debuenas-practicas/decalogo
Some of these indicators were also listed in the transparency index of local councils (Transparency International Spain, 2010). For the second and final wave, we will add some new indicators, until there are 52 indicators in total, in order to adapt the analysis to the Spanish transparency law.

The content analysis coding includes four thematic blocks: indicators aimed at identifying the composition of the council; indicators that provide information on how the administration and the local government operates; indicators linked to current information about the municipality, including their awareness of transparency; and indicators that provide public information about the local council and contact details. In this research, we will focus on the two last blocks, that is, public information and citizen participation tools on each website:

A) Indicators related to the public information provided about the local government and contact details:

- Does it include news, information, and/or opinions on the actions of members of the government related to government management?

- Does it include news, information and/or opinions on the actions of members of the opposition, and/or political groups related to the control of government management?

- Does it include information on the plenary sessions development (motions proposed by different political parties, debates, and agreements)?

- Does it include historical information on the municipality?

- Does it include basic information about the council (geographical position, population, social diversity, economic activity, etc?

- Does it include municipal agendas and citizen activities?

- Does it include contact with the person responsible for press, information, and/or communication of the council, whether technician or politician?

B) Indicators related to tools for citizen participation and democratic control:

- Does it include regulation concerning citizen participation?

- Does it include information about other types of citizen participation mechanisms (sectoral council, city council, territorial council, etc.)?

- Does it include proceedings of the meetings of other mechanisms or participating bodies mentioned in the previous indicator?

- Does it include a directory of organizations and associations of the municipality, and/or registration of interest groups?

- Does it include consultation and/or participation tools on current topics of local interest?

- Does it include a list of services provided (letter of services) and commitments for citizens?

- Does it include tools to evaluate the services and to make complaints or suggestions about how they work?

We gathered all the information based on a national sample with $\mathrm{N}=394$ municipalities websites corresponding to those municipalities with 10,000 or more inhabitants, that were differentiated by geographic location and municipa- 
lity size (inhabitants). In total, our sample included 14 out of the 17 Spanish autonomous communities²: Región de Murcia (7,9\%), Cantabria (2,5\%), Castilla-León (3,3\%), País Vasco (0,5\%), La Rioja (0,5\%), Comunidad de Madrid (2,3\%), Cataluña (34\%), Comunidad Valenciana (24,4\%), Castilla La Mancha (6,3\%), Islas Baleares (5,6\%), Principado de Asturias $(5,3 \%)$, Extremadura $(3,3 \%)$, Comunidad foral de Navarra $(2,5 \%)$, and Andalucía (1,5\%). Even if this sample is not representative of all the national Spanish municipalities with 10,000 or more inhabitants, it can be valid for a first-time descriptive and comparative analysis of transparency in citizens' participation tools and public information provided by Spanish municipalities' websites.

\section{Larger municipalities would have a grea- ter degree of transparency and encoura-} ge a more fluid relationship with citizens

The content analysis was conducted during the spring months of 2015, just two months after the Spanish transparency law was fully in force at the regional and local levels. Data were initially manually coded by pairs of coders, with a second review by a third coder. After that, all the data were recorded in an Excel spreadsheet and then transferred to the platform's content management tool.

A simple frequency analysis was conducted with all the information gathered using the statistical software SPSS.23 in order to compare municipalities' scores and see differences among autonomous communities. The analysis also included some crosstabs based on municipality size to test our first hypothesis. Finally, we construct a transparency level index based on the score that each municipality obtained on the transparency level related to the information about the local representatives and government, the transparency linked to management of economic resources and, finally, the transparency related to public information about the local government and contact details among municipality size. Based on this score, we grouped municipalities into low, medium, and high transparency categories and then tested our second hypothesis related to possible differences in participation level indicators.

\section{Results}

We analyzed the frequencies of each of the indicators included in each block and established comparisons among regions. After this descriptive assessment, the main two hypothesis of the study were tested in order to identify relevant factors that could explain data differences.

A) Transparency indicators related to public information about the local government and contact details.

This type of general information is the easiest for municipalities to provide. The websites usually offered historical information and official data of the municipality (85.5\%). This transparency indicator was relatively high among all communities, with the exception of Andalucía (50\%), CastillaLeón (61.5\%) and Madrid (66.7\%).

Information about municipal agenda and citizen activities was also quite frequent among all Spanish regions (90.1\%), although Castilla-León (61.5\%), Región de Murcia (64.5\%) and Andalucía (67\%) showed it with less frequency.

In the case of basic information about the council one out of three municipalities websites included it (66.2\%). However, in the case of Madrid (22.2\%), Comunidad Valenciana $(36.5 \%)$ and Islas Baleares $(40.9 \%)$ this information was significantly lower.

However, we find important differences depending on if news stories and opinions had to do with actions of members of the government (88.8\%) or if it was news on the actions of the opposition, where it was still anecdotal (15.2\%). Some differences can be detected among communities, where Navarra (70\%), Islas Baleares (72.7\%). and CastillaLa Mancha (76.9\%) show lower percentages of information from the government compared to the rest of the communities. However, Cataluña (38.1\%) showed the highest percentage of information published about opposition parties.

Information related the plenary sessions development is presented in $32.5 \%$ of the websites. However, there were also significant differences among communities, with Cataluña being the region with the highest percentage (72.4\%), followed by Islas Baleares $(36.4 \%)$, and Extremadura (30.8\%).

It should be also noted that contact information related to the person responsible for press, information, and/or communication of the council, whether a technician or politician, was sometimes missing--less than half of the websites included a link to the press officer. This was the indicator where we found more differences among all regions, where Cataluña (81.3\%), Extremadura (46.2\%) and Madrid (44.4\%) show higher percentages than the rest.

B) Tools for citizen participation and democratic control.

The participation and control tools were still very unsatisfactory in almost all local councils. Although there was a greater sensitivity to open channels of citizen participation, our data showed a deficit situation in the existence of such

Table 1. Transparency indicators related to public information about the local government and contact details

\begin{tabular}{|l|c|}
\hline \multicolumn{1}{|c|}{ Indicators } & Percent \\
\hline $\begin{array}{l}\text { News, information, and/or opinions on the actions of } \\
\text { members of the government related to the government } \\
\text { management }\end{array}$ & 88.8 \\
\hline $\begin{array}{l}\text { News, information, and/or opinions on the actions of } \\
\text { members of the opposition and/or political groups related } \\
\text { to the control of government management }\end{array}$ & 15.2 \\
\hline $\begin{array}{l}\text { Information on the plenary sessions development (mo- } \\
\text { tions proposed by political parties, debates, and agree- } \\
\text { ments) }\end{array}$ & 32.5 \\
\hline \begin{tabular}{l} 
Historical information on the municipality \\
\hline $\begin{array}{l}\text { Basic information about the council (geographical posi- } \\
\text { tion, population, social diversity, economic activity, etc.) }\end{array}$
\end{tabular} & 66.2 \\
\hline \begin{tabular}{l} 
Municipal agenda and citizen activities \\
\hline $\begin{array}{l}\text { Contact with the person responsible for press, information } \\
\text { and/or communication of the council, whether technician } \\
\text { or politician }\end{array}$
\end{tabular} & 42.4 \\
\hline
\end{tabular}


tools. In fact, only half of the websites included some regulation concerning participation (51.8\%). For the rest, participation was only considered a real task for their transparency aims. In this sense, we found some differences, where Navarra (20\%), Cantabria (30\%), and Castilla-La Mancha (36\%) had even lower percentages.

\section{Those municipalities that scored higher on transparency also got a higher per- centage on participation}

Something as simple as including a directory or list of the local organizations and associations of the municipality was only present in $61.9 \%$ of the websites, although Cataluña (89.6\%), Madrid (77.8\%), and Navarra (70\%) presented higher percentages. The frequency appearance of a list of services provided by the local council or other commitments with citizens was even worse, with only one out of four websites including it. In this sense, there were differences among some important regions like Cataluña (with the highest percentage, $46.3 \%$ ) compared to Madrid (with the lowest, 0\%).

In the local context, there were some specific mechanisms or entities for participation that were in force as territorial councils, city councils, sector councils, etc. However, our data pointed out that information about those mechanisms for participation were less frequent than expected, with only $37.3 \%$ of the websites including it. Among all Spanish autonomous communities, Cataluña had the highest score (77.6\%). With less differences among regions, only $15.7 \%$ also included some proceedings of the meetings of those mechanisms or entities for participation.

For most of the councils, citizen participation and democratic control were reduced to include tools to evaluate the services and to make complaints or suggestions about how they work. This virtual "complaints box" was present in $76.6 \%$ of the cases - lower in Madrid (55.6\%) and Castilla-La Mancha (64\%)- as the most frequent tool for public partici-
Table 2. Indicators related tools for citizen participation and democratic control

\begin{tabular}{|l|c|}
\hline \multicolumn{1}{|c|}{ Indicators } & Percent \\
\hline Regulation concerning citizen participation & 51.8 \\
\hline $\begin{array}{l}\text { Information about other types of citizen participation } \\
\text { mechanisms (sectoral council, city council, territorial } \\
\text { council, etc.) }\end{array}$ & 37.3 \\
\hline $\begin{array}{l}\text { Proceedings of the meetings of other mechanisms or } \\
\text { participation bodies mentioned in the previous indicator }\end{array}$ & 15.7 \\
\hline $\begin{array}{l}\text { Directory of organizations and associations of the munici- } \\
\text { pality and/or registration of interest groups }\end{array}$ & 61.9 \\
\hline $\begin{array}{l}\text { Tools of consultation and/or participation on current } \\
\text { topics of local interest }\end{array}$ & 33.2 \\
\hline $\begin{array}{l}\text { List of services provided (letter of services) and com- } \\
\text { mitments with the citizens }\end{array}$ & 24.6 \\
\hline $\begin{array}{l}\text { Tools to evaluate the services and to make complaints or } \\
\text { suggestions about how they work }\end{array}$ & 76.6 \\
\hline
\end{tabular}

pation. There were also some other tools of consultation on current topics of local interest, but there was still a pending matter for most of the municipalities (only 33.2\% included it), with the exception of Cataluña, that had a higher percentage (55.2\%).

C) Differences in transparency and participation level depended on the size of the municipality.

Our first hypothesis indicated that the larger the size are the better results in participation and transparency are. So that larger municipalities would have a greater degree of transparency and encourage a more fluid relationship, thanks to the technologies used, than those with a smaller population, mainly due to the greater availability of resources.

Our data definitively showed relevant and statistically significant differences in transparency and participation level depending on municipality size. In fact, as table 3 points out, those municipalities with more than 50,000 habitants

Table 3. Differences in transparency indicators related to public information about the local government and contact details by municipality size. $* \mathrm{P}<0.05$; $* * \mathrm{P}<0.01$

\begin{tabular}{|c|c|c|c|c|}
\hline Indicators & $\begin{array}{c}10,000- \\
20,000 \\
\text { inhabitants } \\
\%\end{array}$ & $\begin{array}{c}20,001- \\
50,000 \\
\text { inhabitants } \\
\%\end{array}$ & $\begin{array}{c}\text { More than } \\
50,001 \\
\text { inhabitants } \\
\%\end{array}$ & $\begin{array}{l}\text { Chi square } \\
\text { signification }\end{array}$ \\
\hline $\begin{array}{l}\text { News, information, and/or opinions on the actions of members of the govern- } \\
\text { ment related to the government management }\end{array}$ & 81.5 & 92.3 & 97.6 & $0.000^{* *}$ \\
\hline $\begin{array}{l}\text { News, information, and/or opinions on the actions of members of the opposi- } \\
\text { tion and/or political groups related to the control of government management }\end{array}$ & 11.9 & 11.3 & 28.6 & $0.001^{* *}$ \\
\hline $\begin{array}{l}\text { Information on the plenary sessions development (motions proposed by } \\
\text { political parties, debates and agreements) }\end{array}$ & 29.2 & 34.5 & 35.7 & 0.471 \\
\hline Historical information on the municipality & 90.5 & 83.8 & 78.6 & $0.030^{* *}$ \\
\hline $\begin{array}{l}\text { Basic information about the council (geographical position, population, social } \\
\text { diversity, economic activity, etc.) }\end{array}$ & 66.7 & 57.7 & 79.8 & $0.003^{* *}$ \\
\hline Municipal agenda and citizen activities & 85.1 & 94.4 & 92.9 & $0.010^{* *}$ \\
\hline $\begin{array}{l}\text { Contact with the person responsible for press, information and/or communi- } \\
\text { cation of the council, whether technician or politician }\end{array}$ & 36.3 & 42.3 & 54.8 & $0.020^{* *}$ \\
\hline
\end{tabular}


Table 4. Differences related to tools for citizen participation and democratic control by municipality size. ${ }^{*} \mathrm{P}<0.05 ; * * \mathrm{P}<0.01$

\begin{tabular}{|c|c|c|c|c|}
\hline Indicators & $\begin{array}{c}10,000-20,000 \\
\text { inhabitants } \\
\%\end{array}$ & $\begin{array}{c}20,001-50,000 \\
\text { inhabitants } \\
\%\end{array}$ & $\begin{array}{c}\text { More than } \\
50,001 \\
\text { inhabitants } \\
\%\end{array}$ & $\begin{array}{l}\text { Chi square } \\
\text { signification }\end{array}$ \\
\hline Regulation concerning citizen participation & 35.1 & 51.4 & 85.7 & $0.000^{* *}$ \\
\hline $\begin{array}{l}\text { Information about other types of citizen participation mechanisms (secto- } \\
\text { ral council, city council, territorial council, etc.) }\end{array}$ & 30.4 & 33.8 & 57.1 & $0.000^{* *}$ \\
\hline $\begin{array}{l}\text { Proceedings of the meetings of other mechanisms or participation bodies } \\
\text { mentioned in the previous indicator }\end{array}$ & 11.3 & 11.3 & 32.1 & $0.000^{* *}$ \\
\hline $\begin{array}{l}\text { Directory of organizations and associations of the municipality and/or } \\
\text { registration of interest groups }\end{array}$ & 57.7 & 57.7 & 77.4 & $0.004^{* *}$ \\
\hline Tools of consultation and/or participation on current topics of local interest & 20.8 & 33.8 & 57.1 & $0.000^{* *}$ \\
\hline $\begin{array}{l}\text { List of services provided (letter of services) and commitments with the } \\
\text { citizens }\end{array}$ & 21.4 & 19.7 & 39.3 & $0.002^{* *}$ \\
\hline $\begin{array}{l}\text { Tools to evaluate the services and to make complaints or suggestions } \\
\text { about how they work }\end{array}$ & 72.0 & 76.1 & 86.9 & $0.003^{* *}$ \\
\hline
\end{tabular}

scored higher than those with smaller sizes in almost all the transparency indicators. Most of the relationships between municipality size and the score obtained in each indicator were also statistically significant (chi square $\leq 0.05$ ).

There were only two cases worthy of comment. First, the case of the information on the plenary sessions development, where differences among municipalities' sizes were not statically significant. The second one was related the historical information on the municipality, where smaller sized municipalities scored higher than bigger ones. This was an expected result considering that small towns usually focused their public information on this type of general information.

When we analyzed indicators linked to tools for citizen participation and democratic control, we also found relevant differences among municipality size. As table 4 shows, municipalities with more population present had a greater number of tools for citizen participation. In this case, all the indicators were statistically significant (chi square $\leq 0.05$ ), with clear differences among municipality size.

As expected in our first hypothesis, the population size definitively made differences when we were measuring participation and transparency level of the municipalities' websites.

D) Differences in participation level depending on the transparency score.

Our second hypothesis pointed out possible differences in the participation indicators depending on the score obtained in our transparency index (based on the transparency level related to the information on the local representatives and government, the transparency linked to management of economic resources on the other hand and, finally, the transparency related to public information about the local government and contact details among municipality size). In that sense, our hypothesis suggests that the higher score in transparency the higher score also in citizen participation level indicators.
Based on that transparency index, we grouped our municipalities sample into three levels of transparency: low, medium, and high. Table 5 shows the significant relationship (chi square $\leq 0.00$ ) between transparency level variable and the municipality size variable. As before explanations, results underline that bigger municipalities scored higher in transparency compared to smaller municipalities.

Data also corroborate our second hypothesis by considering the significant and statistical relationship between all participation indicators and the transparency level variable (chi square $\leq 0.00$ ). These results meant that those municipalities that scored higher on transparency also got a higher percentage on participation, so that there was a positive and relevant association between these variables, as Table 6 shows.

\section{Conclusions}

This research presents some proposals on theoretical and research aspects on transparency in public information and participation tools at the local government level. The objective was to analyze and assess how local councils used digital technologies in their relationship with citizens. Our findings show that transparency in local government websites presents deficiencies and is lacking in nearly all the indicators used to measure it. But also, due to a steady and

Table 5. Differences related tools for citizen participation and democratic control depending on municipality size

\begin{tabular}{|l|c|c|c|}
\hline Transparency & $\begin{array}{c}\mathbf{1 0 , 0 0 0 - 2 0 , 0 0 0} \\
\text { inhabitants } \\
\%\end{array}$ & $\begin{array}{c}\mathbf{2 0 , 0 0 1 - 5 0 , 0 0 0} \\
\text { inhabitants } \\
\%\end{array}$ & $\begin{array}{c}\text { More than } \\
\mathbf{5 0 , 0 0 1} \\
\text { inhabitants } \\
\%\end{array}$ \\
\hline low & $\mathbf{5 1 . 8}$ & 23.2 & 6.0 \\
\hline medium & 37.5 & $\mathbf{6 0 . 6}$ & 51.2 \\
\hline high & 10.7 & 16.2 & $\mathbf{4 2 . 9}$ \\
\hline
\end{tabular}


Table 6. Differences related tools for citizen participation and democratic control by transparency level in municipalities. $* P<0.05 ; * * P<0.01$

\begin{tabular}{|c|c|c|c|c|}
\hline \multirow{2}{*}{ Indicators } & \multicolumn{3}{|c|}{ Transparency } & \multirow{2}{*}{$\begin{array}{l}\text { Chi square } \\
\text { significa- } \\
\text { tion }\end{array}$} \\
\hline & $\begin{array}{l}\text { low } \\
\%\end{array}$ & $\begin{array}{l}\text { medium } \\
\%\end{array}$ & $\begin{array}{l}\text { high } \\
\%\end{array}$ & \\
\hline Regulation concerning citizen participation & 20.8 & 58.3 & 85.7 & $0.000^{* *}$ \\
\hline $\begin{array}{l}\text { Information about other types of citizen participation mechanisms (sectoral council, city } \\
\text { council, territorial council, etc.) }\end{array}$ & 9.6 & 35.4 & 87.0 & $0.000^{* *}$ \\
\hline $\begin{array}{l}\text { Proceedings of the meetings of other mechanisms or participation bodies mentioned in the } \\
\text { previous indicator }\end{array}$ & 0.8 & 5.7 & 64.9 & $0.000 * *$ \\
\hline $\begin{array}{l}\text { Directory of organizations and associations of the municipality and/or registration of interest } \\
\text { groups }\end{array}$ & 43.2 & 62.5 & 90.9 & $0.000^{* *}$ \\
\hline Tools of consultation and/or participation on current topics of local interest & 10.4 & 30.2 & 77.9 & $0.000^{* *}$ \\
\hline List of services provided (letter of services) and commitments with the citizens & 12.0 & 16.1 & 66.2 & $0.000^{* *}$ \\
\hline Tools to evaluate the services and to make complaints or suggestions about how they work & 65.6 & 74.5 & 100 & $0.000^{* *}$ \\
\hline
\end{tabular}

sustained growth in the transparency reflected on institutional websites, these can be considered as a useful tool for improving the connection between citizens and politics.

From this analysis of 394 websites of local councils corresponding to those municipalities with 10,000 or more inhabitants that were differentiated by geographic location and municipality size (inhabitants), the two initial hypotheses have been confirmed.

First, our data definitively showed relevant and statistically significant differences in transparency and participation level depending on municipality size. Those municipalities with more than 50,000 inhabitants scored higher than those with a smaller size in almost all the transparency indicators. Most of the relationships between municipality size and the score obtained in each indicator were also statistically significant. The confirmation of the hypothesis $\mathrm{H} 1$, corroborates previous investigations with this same conclusion (MorenoSardà et al., 2015, p. 156; Subires-Mancera; Cuartero-Naranjo, 2015, p. 83). In this sense, it would be interesting to investigate the relationship between investment in digital tools and transparency level for future research. There were two indicators in which the differences in municipality size was not statically significant. These exceptions suggest that transparency was also a matter of political will.

Data also confirmed our second hypothesis by considering the significant and statistical relationship between all participation indicators and the transparency level variable. In this sense, those municipalities that scored higher on transparency also got a higher percentage on citizen participation.

In short, our study reinforces that transparency requires investment of resources along with political will. An important point linked to the necessity of implementing transparency is that it promotes greater citizen participation. In turn, participation can help to reduce citizens' distrust towards local institutions. Undoubtedly, more research in this area, which includes all the Spanish municipalities, is crucial, so that public institutions can take advantage of the possibilities of new technologies in strengthening democracy.

\section{Notes}

1. These studies were carried out in an individual level, that is, analyzing a one single region, or comparing two regions as maximum.

2. Although some Spanish regions like Galicia, Canarias, and Aragón, were included in the first national study, we decided to take them out of the sample because data from these communities were gathered before the Transparency law implementation (before 2015).

\section{Acknowledgement}

This research has been funded by the Spanish Ministry of Education and Science, under the project "Public communication, transparency, accountability and participation in the local governments" (Ref: CSO 2013-46997-R) (2014-2016).

\section{References}

Alguacil-Gómez, Julio (2006). "Los desafíos del nuevo poder local: ¿hacia una estrategia relacional y participativa en el gobierno de la ciudad?". En: Alguacil-Gómez, Julio (ed.). Poder local y participación democrática. Barcelona: El Viejo Topo, pp. 9-47. ISBN: 9788496356788

Bauhr, Monika; Grimes, Marcia (2014). “Indignation or resignation: The implications of transparency for societal accountability". Governance, v. 27, n. 2, pp. 291-320.

https://doi.org/10.1111/gove.12033

Beltrán-Orenes, Pilar; Martínez-Pastor, Esther (2016). “Grado de cumplimiento de las leyes de transparencia, acceso y buen gobierno, y de reutilización de los datos de contratación de la Administración central española". El profesional de la información, v. 25, n. 4, pp. 557-567.

https://doi.org/10.3145/epi.2016.jul.05

CIS (Centro de Investigaciones Sociológicas) 2016. Barómetro estudio n. 3156, octubre 2016.

http://datos.cis.es/pdf/Es3156mar_A.pdf

Cabezuelo-Lorenzo, Francisco; Rey-García, Pablo; TapiaFrade, Alejandro (2016). "Análisis de las herramientas de 
control ciudadano sobre los representantes públicos: La transparencia informativa municipal en Castilla y León". Revista latina de comunicación social, n. 71, pp. 1.261-1.279. https://doi.org/10.4185/RLCS-2016-1145

España (2013). "Ley 19/2013, de 9 de diciembre, de transparencia, acceso a la información pública y buen gobierno". BOE, n. 295, 10 de diciembre, pp. 97922-97952.

https://goo.gl/TD3EUJ

Gértrudix, Manuel; Gertrudis-Casado, María-Carmen; Álvarez-García, Sergio (2016). "Consumption of public institutions' open data by Spanish citizens". El profesional de la información, v. 25, n. 4, pp. 535-544.

https://doi.org/10.3145/epi.2016.jul.03

Guerrero, Enrique (2006). "Responsabilidad y control: rendición de cuentas del Gobierno". En: Martínez, Antonia (ed.). Representación y calidad de la democracia en España. Madrid: Tecnos, pp. 165-178. ISBN: 8430944559

Kim, Soonhee; Lee, Jooho (2012). "E-participation, transparency, and trust in local government". Public administration review, v. 72, n. 6, pp. 819-828.

https://doi.org/10.1111/j.1540-6210.2012.02593.x

Labio-Bernal, Aurora (2006). Comunicación, periodismo y control informativo. Barcelona: Anthropos. ISBN: 9788476588000

Lindstedt, Catharina; Naurin, Daniel (2010). "Transparency is not enough: Making transparency effective in reducing corruption". International political science review, v. 31, n. 3, pp. 301-322.

https://doi.org/10.1177/0192512110377602

Lizcano-Álvarez, Jesús (2012). "Transparencia". Eunomía, Revista en cultura de la legalidad, n. 3, pp. 160-166. http://e-revistas.uc3m.es/index.php/EUNOM/article/ view/2127/1058

Manfredi-Sánchez, Juan-Luis; López-Cepeda, Ana-María; Álvarez-Peralta, Miguel; Saiz-Echezarreta, Vanesa; ReigCruañes, José (2016). "Transparencia y rendición de cuentas de los municipios de Castilla-La-Mancha". Barataria, n. 21, pp. 175-189.

https://doi.org/10.20932/barataria.v0i21.304

Molina-Rodríguez-Navas, Pedro (2008). “Ciberperiodismo e interactividad: entre la participación y la apariencia". Anàlisi. Quaderns de comunicació i cultura, v. 36, pp. 175-182. http://www.raco.cat/index.php/Analisi/article/view/94530/119745

Moreno-Sardà, Amparo; Corcoy-Rius, Marta; Molina-Rodríguez-Navas, Pedro; Toledano-Buendía, Samuel; Vera-Balanza, María-Teresa; Rodríguez-Beijo, Vanessa; Simelio-Solá, Núria (2015). "Comparativo de 230 webs de ayuntamientos de municipios de más de 20.000 habitantes". En: MolinaRodríguez-Navas, Pedro (coord.) Transparencia de la comunicación pública local. El Mapa Inforparticipa (http://www.mapainfoparticipa.com). Cuadernos artesanos de comunicación, n. 78. La Laguna: Latina, pp. 149-157. ISBN: 9788415698951

Moreno-Sardà, Amparo; Molina-Rodríguez-Navas, Pedro; Corcoy-Rius, Marta (2013a). "La información de las administraciones públicas locales. Las webs de los ayuntamien- tos de Cataluña". Revista latina de comunicación social, n. 68, pp. 502-528.

https://doi.org/10.4185/RLCS-2013-987

Moreno-Sardà, Amparo; Molina-Rodríguez-Navas, Pedro; Corcoy-Rius, Marta; Aguilar-Pérez, Antonio; Borràs-Farran, Miquel (2013b). “Infoparticip@: periodismo para la participación ciudadana en el control democrático. Criterios, metodologías y herramientas". Estudios sobre el mensaje periodístico, v. 19, n. 2, pp. 783-803.

https://doi.org/10.5209/rev_ESMP.2013.v19.n2.43471

Norris, Pippa (2000). A virtuous circle: Political communications in postindustrial societies. Cambridge: Cambridge University Press. ISBN: 9780521793643

Rebolledo, Marta; Zamora-Medina, Rocío; Rodríguez-Virgili, Jordi (2016). "Transparency, accountability and participation in the local governments: Comparative studies among Spanish Council's websites". Media studies, v. 7, n. 14, pp. 48-64. https://doi.org/10.20901/ms.7.14.5

Reig, Ramón (2009). "Bases teóricas y documentales para el estudio de la Estructura de la información y el análisis estructural de los mensajes". Estudios sobre el mensaje periodístico, n. 15, pp. 385-407.

https://goo.gl/zoGL2V

Stasavage, David (2003). "Transparency, democratic accountability and the economic consequences of monetary institutions". American journal of political science, n. 47, pp. 389-402. https://doi.org/10.1111/1540-5907.00028

Subires-Mancera, María-Purificación; Cuartero-Naranjo, Antonio (2015). "Las webs de los ayuntamientos de Andalucía de municipios de 10.001 a 50.000 habitantes". En Molina-Rodríguez-Navas, Pedro (coord.) Transparencia de la comunicación pública local. El Mapa Inforparticipa (www. mapainfoparticipa.com). Cuadernos artesanos de comunicación, n. 78. La Laguna: Latina, pp. 69-85. ISBN: 97884 15698951

Tornos-Mas, Joaquín; Arroyo-Díez, Alfonso; Martínez-Martínez, Mar; López-Pagán, Juana (2012). Transparencia, rendición de cuentas y participación: una agenda común para la cohesión social y la gobernanza en América Latina. Barcelona: Programa URB-AL III.

https://www1.diba.cat/uliep/pdf/52249.pdf

Transparency International Spain (2010). Índice de transparencia de los ayuntamientos.

http://webantigua.transparencia.org.es/ita_2010/ metodologia_utlizada_en_el_ita_2010.pdf

Verge, Tània (2007). “Modelos alternativos de participación ciudadana en los partidos políticos españoles: un estudio del PSOE; el PP e IU". Revista española de ciencia política, n. 17 , pp. $155-177$.

Villoria, Manuel (2011). "La rendición de cuentas en la democracia". Temas para el debate, n. 204, pp. 32-34. http://www.fundacionsistema.com/revista-temas

Zamora-Medina, Rocío (ed.) (2011). Claves para gestionar la comunicación política local. Zamora: Comunicación Social Ediciones y Publicaciones. ISBN: 9788492860852 